\title{
The Mistakes That Are Made by Students with Regard to Functions: Evidence from Erzincan (A Province in Turkey)
}

\author{
Kani Başibüyük ${ }^{1}$, Ömer Şahin ${ }^{2}$, Burçin Gökkurt $^{3}$, Emrullah Erdem $^{4}$, Yasin Soylu ${ }^{5, *}$ \\ ${ }^{1}$ Refahiye Vocational School, Erzincan University, Turkey \\ ${ }^{2}$ Department of Elementary Mathematics Education, Faculty of Education, Amasya University, Turkey \\ ${ }^{3}$ Department of Elementary Mathematics Education, Faculty of Education, Bartin University, Turkey \\ ${ }^{4}$ Department of Elementary Mathematics Education, Faculty of Education, Adiyaman University, Turkey \\ ${ }^{5}$ Department of Elementary Mathematics Education, Kazim Karabekir Faculty of Education, Ataturk University, Turkey
}

Copyright $\mathrm{O} 2016$ by authors, all rights reserved. Authors agree that this article remains permanently open access under the terms of the Creative Commons Attribution License 4.0 International License

\begin{abstract}
The aim of this study is to identify the mistakes made by ninth grade students in the subject of functions and reveal the reasons for these mistakes. In line with this purpose, the case study method, which is among the qualitative research methods, was used in the study. The study group of the research was composed of 52 Anatolian ninth grade students and four mathematics teachers. Eight open-ended questions were used as the data collection tool. Non-structured interviews were conducted in order to reveal the reasons for the mistakes. The content analysis technique was utilized in analyzing the data. When the obtained findings were examined, it was observed that the majority of the students experienced problems in meaningfully perceiving and expressing the functions. When the data obtained from the interviews was examined, it was observed that the mistakes made by the students resulted from such reasons as lack of conceptual knowledge, memorization-based learning and the fact that they were not ready for the subject.
\end{abstract}

Keywords High School Students, Mistakes in Functions, Causes of Mistakes

\section{Introduction}

Functions, which have a significant place in mathematics teaching programs, are one of the most basic subjects of mathematics. The variety in representations and generalizations rendered the functions different for mathematics [1]. The definition of functions is studied in the literature with different approaches. If the functions are to be defined in a broad term, they can be regarded as a dynamic mechanism (a process that transforms inputs into outputs) that performs a transformation [2]. In Anatolian mathematics course schedules, function is defined as the relationship between two variables (a change in an independent variable like $x$ but a change in a dependent variable like $y$ ). In another approach, function is defined as a special relation that pairs elements from a set with elements from another set [3].

In the beginning, the concepts of change and transformation came forward in the teaching process of functions. Later, when the concept of set became widespread, the rule of correspondence between two sets started to be used [4]. The mental formations in the process of learning the concept of function are composed of movement, process, object and scheme steps [5]. If the categories of students' interpretation of the concept of function are to be listed under certain headings, they can be expressed as follows: perceiving the function as a system of unknown equations, associating the function with solving equations, evaluating it as a formula, perceiving it as a process of operations and perceiving it as a formula system related to graph drawing [6]. In a different study conducted to understand the functions, the difference between the concept of function and the concept image was set forth [7]. Although the concept of function is given with a definition, very few students consider the definitional properties when contemplating the functions. The images of the concepts must be enriched to increase perception and learning. In order to achieve this, examples which will make students contemplate the definitional properties, and on which they will be able to comment, must be presented [8].

Students' learning the subject of functions forms a solid foundation for many subjects. However, it is understood from the conducted studies $[1,7,9,10,11,12,13,14,15,16$, 
$17,18,33$ that students may experience some difficulties and misconceptions due to the fact that the concept of function has an abstract mathematical structure. Some difficulties and mistakes are observed in almost all studies that have been trained on the concept of function. [15] reported that difficulties and mistakes related to the concept can be grouped under three headings, in a general sense; namely, as those related to the definition of functions, those related to the representation and the relationship among them and those related to the mathematical language used in the concept. In our country of Turkey, functions are generally taught in accordance with certain patterns (rule, definition and memorization). Memorization of its features based only on this definition brings along many mistakes and misconceptions [34]. In his study, [2] stated the difficulties and misconceptions that the students experienced in the subject of functions under certain headings as follows:

- Regarding the function as a relation that makes one-to-one (1-1) correspondence.

- Difficulties regarding the notations in list form (ordered pairs).

- Misconceptions of students regarding the function graphs.

- Difficulties and misconceptions of students regarding the algebraic expressions.

- Difficulties regarding the symbols and signs that are used in the subject of functions.

- Difficulties regarding the sub-concepts of functions.

- Difficulties regarding understanding the meaning-based relationships among the representations of the function.

When the related literature is examined, it is observed that the conducted studies generally focus on the subject such as students' misconceptions, mistakes and learning difficulties in the subject of functions $[8,9,10,17,19,20,21,22,23,24$, 25]. Unlike other studies, this study elaborates on the causes of mistakes and errors in the functions in addition to determining the mistakes and errors. Such mistakes and errors have been evaluated by the open-ended questions that are retrieved from the literature review.

As functions are conceptual structures that can be considered the basis of mathematical thinking, it is important for this subject to be understood well by students. As stated above, comprehension of functions is more difficult than other subjects, and this brings along many mistakes and errors. In this respect, this study is also important in that it can reveal the extent to which students comprehend functions and that it offers solutions to this problem. Taking the students of a certain school as subjects can be said to be the restriction of the study.

\section{Purpose of the Study}

This study has two purposes. The first one is to identify the mistakes of ninth-grade students in accordance with the scope of the selected questions. The second one is to identify the causes of such mistakes within the same scope.

\section{Methodology}

The aim of this study is to identify the mistakes made by ninth grade students in the subject of functions and reveal the reasons for these mistakes. In line with this purpose, the case study method, which is among the qualitative research methods, was used in the study. A case study is defined as the method in which one or more situations, environments, programs, social groups or other interdependent systems are examined in detail [26].

\section{Participants}

The study group of the research was composed of 52 ninth grade students and four mathematics teachers who were selected via the simple random sampling method from an Anatolian High School located in a province. The teachers interviewed were assigned codes: $T_{1}, T_{2}, T_{3}$ and $T_{4}$ and the ninth grade students interviewed were given codes ranging from $S_{1}$ to $S_{13}$ in order to keep the identities of the students and teachers in the study group confidential.

\section{Data Collection}

A test, which was composed of eight open-ended questions, was used as the data collection tool. The test was prepared in order to identify the mistakes of the students in the subject of functions. The related literature $[9,16,17,18$, 24] was utilized in order to establish the reliability of the test. The studies conducted on this subject were examined and a question pool composed of 18 questions was formed in the preparation process of the test. Then, the questions were examined by six experts (They are academic staff). The examined questions were evaluated by considering the criteria such as aim, content, duration for answers and level. Lastly, the number of questions was reduced to eight. To utilize the related literature and to consult expert opinion was considered adequate for the reliability and validity of the prepared test.

The non-structured interview technique was used as a data collection tool regarding the second question of the research. The interviews were conducted with 13 students and four teachers. By doing so, an attempt was made to obtain detailed data via maintaining a flexible environment during the interviews. The principle of volunteering was taken as basis in selecting the participants for the interviews, as required by scientific ethics. Students were free to participate or not participate in the study. The purposeful sampling method was used in selecting these 13 participants. The participants were selected based on their written statements (Depending on the answers to each question). The interviews 
were conducted at times deemed suitable by the students in order to perform the interviews in order to create optimum interview conditions. Each conducted interview lasted for approximately 10 to 15 minutes. And interviews recorded by tape.

\section{Data Analysis}

The content analysis technique was used in analyzing the data. The data obtained in the first stage of the data analysis was read by the researcher several times. Answers given for each question were divided into meaningful sections and coded. Then, the researcher performed coding again, three weeks later, to establish coding reliability. The coding reliability percentage was found to be $98 \%$. The frequencies of the answers given to the questions were rendered in numeric form and given as tables in order to allow for objective comments. Moreover, non-structured interviews were conducted with 13 students and four teachers in order to determine the reasons for student mistakes. The sections of the interviews which were related to the research were also featured.

\section{Findings and Interpretation}

This section gives the analysis results regarding the answers given by the participating students to each of the eight open-ended questions that were prepared in the subject of functions. Furthermore, some excerpts from the interviews conducted with the students and teachers were conveyed in this section.

When Table 1 was examined, it was observed that although 21 students answered this question correctly, more than half of the students made various mistakes in answering this question. The mistakes made in this question are as follows: the fact that no element was left unpaired in the domain was considered to single-handedly fulfill the requirement for being a function; it was taught that no element must be left unpaired in the codomain as well; and the requirement for the fact that an element in the domain has only one image was also perceived as a requirement for the elements in the codomain. Non-structured interviews were conducted with the students and teachers in order to research the reasons for the mistakes made by the students. Excerpts from the interviews conducted with one teacher and three students about this question, as well as the answer of one student, are given below.

$\mathbf{S}_{\mathbf{9}}$ : “...It denotes a function since no element was left unpaired in the domain, that is to say, set A. In order for it to denote a function, no element must be left unpaired in the domain. That is what I remember from its definition..."

$\mathbf{S}_{3}$ : “...element ' $c$ ' in set B has more than one image. Since an element cannot have more than one image according to the function denotation rule, this relation is not a function. From its definition..."

$\mathbf{S}_{7}$ : "...It is not a function since there is an unpaired element in set B. In order for a relation to denote a function, no element must be left unpaired in the domain and every element must have an image. From its definition..."

$\mathbf{T}_{\mathbf{2}}$ : “...Since most of the students memorize the rules, they cannot learn the subjects at the conceptual level. The students who made mistakes in this question made those mistakes as they confused the requirements with each other because they memorized the definition of functions..."

Table 1. The Answers Given by the Students to the First Question

\begin{tabular}{ccc}
\hline Frequency & Answers & Basic Foundations of the Answers \\
\hline 21 & $\begin{array}{c}\text { It is a function because no element was left unpaired in the } \\
\text { domain and every element has only one image. }\end{array}$ & The state of being a function was correctly expressed. \\
\hline 15 & It is a function because no element was left unpaired in set A \\
(domain). & $\begin{array}{c}\text { The state of being a function was only associated with the fact } \\
\text { that no element was left unpaired in the domain. }\end{array}$ \\
\hline 6 & It is not a function because there is an unpaired element in set \\
B (codomain). & $\begin{array}{c}\text { The fact that no element was left unpaired in the domain was } \\
\text { generalized and perceived as a requirement for the codomain. }\end{array}$ \\
\hline 3 & It is not a function because "c" in the codomain has two \\
images. & $\begin{array}{c}\text { The state of having an image, which is valid for the elements in } \\
\text { the domain, was also perceived as a requirement for the } \\
\text { elements in the codomain. }\end{array}$ & $\begin{array}{c}\text { Unrelated statements were made because the question was not } \\
\text { fully understood. }\end{array}$ \\
\hline
\end{tabular}


1) $A=\{1,2,3,4\})$ ve $B=\{a, b, c, d, e, f\}$

\section{$f: A \rightarrow B$ olmak üzere $f:(1, b),(2, c)(3, c),(4, e)$ bağıntısı fonksiyon belirtir mi nedenleri ile açıklayınız?}
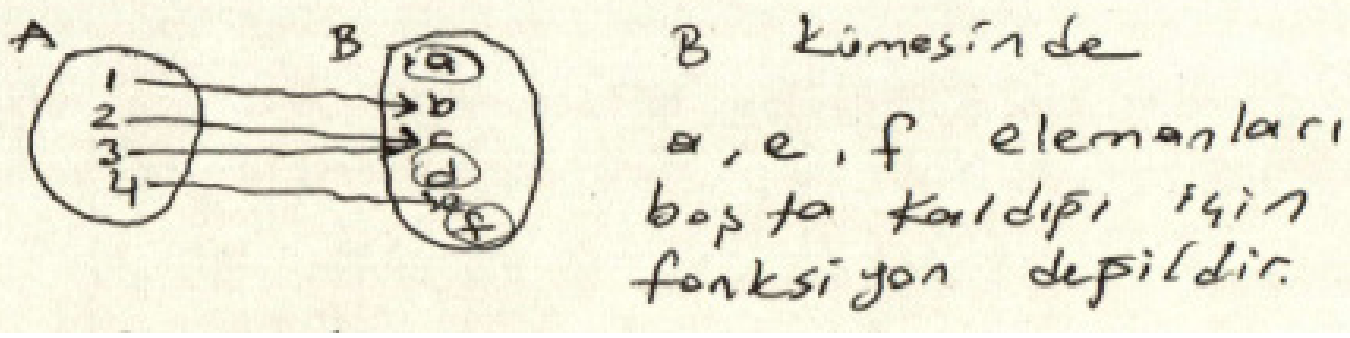

Figure 1. Given by one of the Students Answered the First Question

When the data obtained from the conducted interviews was examined, it was observed that the students misinterpreted the statements "No element is left unpaired" and "Every element must have an image".In view of the interviews conducted with teachers and students, the reason for these mistakes made by the students was associated with the fact that the students were not able to understand the requirements in the definition of functions at the conceptual level.In other words, since they did not know the meanings of the statements "No element is left unpaired" and "Every element must have an image", they perceived the requirements for the domain for the codomain as well in fulfilling these requirements.

Table 2. The Answers Given by the Students to the Second Question

\begin{tabular}{ccc}
\hline Frequency & Answers & $\begin{array}{c}\text { Basic Foundations of the } \\
\text { Answers }\end{array}$ \\
\hline 11 & $f^{-1}(x)=\sqrt{x+4}-2$ & $\begin{array}{c}\text { Inverse of the function was } \\
\text { found correct }\end{array}$ \\
\hline 8 & $\frac{x^{2}-4 x}{2}$ or $x^{2}-4 x$ & $\begin{array}{c}\text { It was associated with the } \\
\text { general formula } f(x)= \\
a x+b, f^{-1}(x)=\frac{x-b}{a}\end{array}$ \\
\hline 5 & $\begin{array}{c}\text { It was correctly } \\
\text { perceived in logic, but } \\
\text { the operation was not } \\
\text { completed. }\end{array}$ & $\begin{array}{c}\text { The process of operation for } \\
\text { finding the inverse of the } \\
\text { function was stated, but } \\
\text { problems were experienced } \\
\text { in continuing the operations. }\end{array}$ \\
\hline 12 & Unrelated answer & $\begin{array}{c}\text { Unrelated statements were } \\
\text { made because the question } \\
\text { was not fully understood. }\end{array}$ \\
\hline 16 & Unanswered & No answer was given. \\
\hline
\end{tabular}

When Table 2 was examined, it was observed that although 11 students gave correct answers to this question, the majority of the students made various mistakes in answering this question. The mistakes made in this question are as follows: operational mistakes and the fact that the method, which is used in finding the inverse of an equation of the first degree, was adapted to an equation of the second degree. Non-structured interviews were conducted with the students and teachers in order to research the reasons for the mistakes made by the students. Excerpts from the interviews conducted with one teacher and one student about this question, as well as the answer of one student, are given below.

$\mathbf{S}_{\mathbf{8}}$ : "...I know what must be done to find the inverse of the function. If the function had not been in the form of an equation of the second degree, I would have completed my operation. However, I was not able to perform the operations in this function..."

$\mathbf{T}_{1}$ : “...Students do not experience much difficulty in taking the inverse of the functions that are represented with the equations of the first degree. However, they make certain mistakes while taking the inverse of the functions that have two or more degrees since they were not able to learn the operations in the exponential numbers and root numbers in detail and since these subjects will be given in the second semester of the ninth grade. We do not feature this kind of question much in the courses due to these mistakes and due to the fact that students are not ready. Furthermore, since the students had not encountered these types of questions much, they associated them with the logic of practically taking the inverse of the function in the equations of the first degree..."

$$
\begin{array}{cl}
\text { 2) } f(x)=x^{2}+4 x \text { ise } f^{-1}(x) \text { i bulunuz } \\
f(x)=x^{2}+4 x & x=y^{2}+4 y \\
y=x^{2}+4 x & x=y \cdot(y+4) \\
x=y^{2}+4 y & \frac{x}{y+6}=y \\
y=f^{-1}(x) &
\end{array}
$$

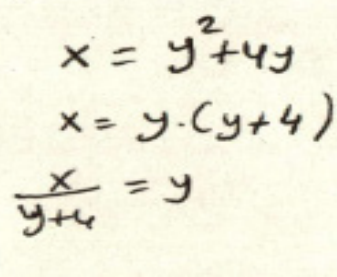

Figure 2. Given by one of the Students Answered the Second Question

As it is also understood from the above-given statements, students experienced great difficulty in taking the inverse of the functions that are represented as the equations that have two or more degrees. They practically associated taking the inverse of the function in the equations of the first degree with the equations of the second degree. In view of the data obtained from the conducted interviews, the basic reasons for the mistakes can be listed as follows: the students were not ready for the operations in the equations of the second 
degree, the rule of taking the inverse of the equations of the first degree was implemented on the equations of the second degree and such types of questions were not given in the courses.

Table 3. The Answers Given by the Students to the Third Question

\begin{tabular}{|c|c|c|}
\hline Frequency & Answers & $\begin{array}{c}\text { Basic Foundations of the } \\
\text { Answers }\end{array}$ \\
\hline 14 & $\begin{array}{c}\text { Since the function } \\
\mathrm{f}(\mathrm{y})=5 y+3 \text { is a variable } \\
\text { dependent on } y \text { and an } \\
\text { operation that gives the } \\
\text { image of the variable, it can } \\
\text { denote a function. }\end{array}$ & $\begin{array}{l}\text { The question was } \\
\text { answered correctly. }\end{array}$ \\
\hline 18 & $\begin{array}{l}\text { The function must not be } \\
f(y) \text { but } f(x) \text { and its } \\
\text { value must not be } 5 y \text { but } \\
5 x \text {. }\end{array}$ & $\begin{array}{c}\text { Since the functions were } \\
\text { generally taken as a } \\
\text { variable dependent on } x \text {, } \\
\text { a different variable was } \\
\text { not evaluated as a } \\
\text { function. }\end{array}$ \\
\hline 7 & Unrelated answer & $\begin{array}{c}\text { Unrelated statements } \\
\text { were made because the } \\
\text { question was not fully } \\
\text { understood. }\end{array}$ \\
\hline 13 & Unanswered & No answer was given. \\
\hline
\end{tabular}

When Table 3 is examined, it is observed that 18 students stated that the relation $\mathrm{f}(\mathrm{y})=5 y+3$ cannot be a function. Thirteen students did not answer this question. Excerpts from the interviews conducted with one teacher and one student to determine the reason for this mistake, as well as the answer of the same student, are given below.

$\mathbf{S}_{11}$ : “...In order for this relation to denote a function, it must be $f(x)=5 x+3$. The $x$ must be absolutely present in order for it to be a function. Functions are composed of variables dependent on $x$..."

$\mathbf{T}_{3}$ : “...Students made mistakes since functions were always expressed as variables dependent on $x$ while they were studied. Since this is also the case with the books, the students evaluate the functions as dependent on x..."

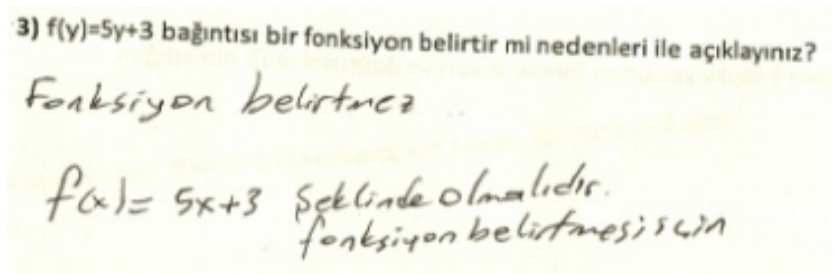

Figure 3. Given by one of the Students Answered the Third Question

Since the functions are generally expressed as a variable dependent on $x$, whether or not a relation, which was expressed with a variable dependent on $y$, was a function caused many students to make mistakes. It is also understood from the conducted interviews that this condition results from the fact that the functions are constantly defined as dependent on the $x$.
Table 4. The Answers Given by the Students to the Fourth Question

\begin{tabular}{ccc}
\hline Frequency & Answers & $\begin{array}{c}\text { Basic Foundations of the } \\
\text { Answers }\end{array}$ \\
\hline 6 & $\begin{array}{c}\text { Domain: set A, Image } \\
\text { set: } 2,3,4, \text { Codomain: N }\end{array}$ & $\begin{array}{c}\text { The question was } \\
\text { answered correctly. }\end{array}$ \\
\hline 3 & $\begin{array}{c}\text { Domain: set A, Image } \\
\text { set: N, Codomain: } 2,3,4\end{array}$ & $\begin{array}{c}\text { They misperceived the } \\
\text { image set and the } \\
\text { codomain. }\end{array}$ \\
\hline 8 & $\begin{array}{c}\text { Domain: set A, Image set } \\
\text { and Codomain: 2,3,4, }\end{array}$ & $\begin{array}{c}\text { They perceived the image } \\
\text { set and the codomain as the } \\
\text { same concepts }\end{array}$ \\
\hline 10 & Domain: set A, Image & $\begin{array}{c}\text { No answer was given } \\
\text { related to the codomain. }\end{array}$ \\
\hline 11 & $\begin{array}{c}\text { Domain: set A, } \\
\text { Codomain: 2,3,4 }\end{array}$ & $\begin{array}{c}\text { The image set was } \\
\text { perceived as the codomain. }\end{array}$ \\
\hline 9 & Unrelated answer & $\begin{array}{c}\text { Unrelated statements were } \\
\text { made because the question } \\
\text { was not fully understood. }\end{array}$ \\
\hline
\end{tabular}

When Table 4 was examined, it was observed that almost no students were able to provide a correct answer to this question. Although most of the students correctly represented the domain, they made mistakes in representing the codomain and the image set. The mistakes made by the students are as follows: confusing the image sets with the codomain and perceiving the codomain and the image set as the same concepts. Excerpts from the interviews conducted with two students and one teacher to determine the reasons for these mistakes are given below.

$\mathbf{S}_{1}$ : “...In this question, the domain set is set $A$, that is to say $\{1,2,3\}$. The codomain is composed of the values $\{2,3,4\}$ that are obtained by substituting the elements within set $A$ in their respective places in the function. The image set is composed of natural numbers. The codomain and image set are set $B$..."

$\mathbf{S}_{5}$ : “...The domain set is set $A$. The codomain and image sets are set $\{2,3,4\}$, which is obtained by writing the elements within the domain in their respective places in the function. The codomain and image sets have the same meaning...."

$\mathbf{T}_{\mathbf{4}}$ : “...The concepts of domain, codomain and image sets are given to the students in a comprehensible manner. However, students do not take an interest in these concepts since they attach more importance to the expressions that are studied as questions in books or the expressions that they frequently encounter. Therefore, many of them make mistakes as they did in this question. In other words, such types of concepts are not given much emphasis..."

When the above-given data is examined, it is observed that a majority of the students made mistakes in perceiving the concepts of image set and codomain. It is a worrisome fact that many students made mistakes despite the fact that these concepts are the most basic concepts of functions. This fact shows that the students were not able to fully internalize what codomain and image set meant. As it is also understood from the interview conducted with a teacher on this question, the basic reasons for those mistakes are the fact that the students rather take an interest in the concepts that they may 
encounter in a question or the fact that sourcebooks do not place much emphasis on the basic concepts.

Table 5. The Answers Given by the Students to the Fifth Question

\begin{tabular}{|c|c|c|}
\hline Frequency & Answers & $\begin{array}{c}\text { Basic Foundations of the } \\
\text { Answers }\end{array}$ \\
\hline 0 & $\begin{array}{c}g o f(x)=g(f(x))= \\
x^{4}+4 x^{2}, f o g(x) \\
\text { cannot be defined. }\end{array}$ & $\begin{array}{l}\text { Correct answer for the } \\
\text { question. }\end{array}$ \\
\hline 8 & $\begin{array}{l}f \circ g(x)=f(g(x)) \\
=x^{4}-8 x^{2}+18 \\
g o f(x)=g(f(x)) \\
=x^{4}+4 x^{2}\end{array}$ & $\begin{array}{l}\text { Compounds of the functions } \\
\text { were correctly expressed. } \\
\text { However, it was not stated } \\
\text { that the function } f o g(x) \\
\text { could not be defined. }\end{array}$ \\
\hline 18 & $\begin{array}{l}f o g(x) \\
=f(g(x)), g \circ f(x) \\
=g(f(x))\end{array}$ & $\begin{array}{l}\text { Students logically expressed } \\
\text { the compound function. } \\
\text { However, operational } \\
\text { mistakes were made and the } \\
\text { state of being undefined was } \\
\text { not mentioned. }\end{array}$ \\
\hline 15 & Unrelated answer & $\begin{array}{l}\text { Unrelated statements were } \\
\text { made because the question } \\
\text { was not fully understood. }\end{array}$ \\
\hline 11 & Unanswered & No answer was given. \\
\hline
\end{tabular}

It is seen from Table 5 that none of the students were able to provide a correct answer to this question. Eight students expressed $f \circ g(x)$ and $g o f(x)$ but they did not mention that the function $f \circ g(x)$ was not defined. Although 18 students logically expressed $f \circ g(x)$ and $g o f(x)$, they made operational mistakes with different digits in squaring the equation of the second degree. Excerpts from the interviews conducted with one student and two teachers to determine the reasons for these mistakes are given below.

$\mathbf{S}_{12}$ : “...From what I understand of this question, I have to find the compounds of the given functions. In order to find $f \circ g(x)$, we write $g$ where we see $x$ in $f$. Similarly, in order to find $g o f(x)$, we write $f$ where we see $x$ in $g$. I know this rule, but I do not know what requirements must be fulfilled in order for the compound function to become defined..."

$\mathbf{T}_{1}$ : “... When the subject of compound functions is given to the students, the definition of the typical compound function is given, as in this question. However, no emphasis is placed upon the state of being defined. This gave us certain results since this subject was not studied in the questions. Nevertheless, I think such details must be given..."

$\mathbf{T}_{\mathbf{4}}$ : "....Since the compound function is defined as $R \rightarrow R$, the students do not encounter the state of not being defined, as in the case with this question. Moreover, the fact that the students were not ready for squaring an equation of the second degree caused such results..."

The fact that no correct answer was given to this question shows that the students were not able to perceive the definition of the compound function. Furthermore, the vast number of unrelated answers and blank answers is interesting. It can also be understood from the conducted interviews that the most significant reason for this condition is the fact that the students had not previously encountered the compound function's state of being defined or not defined. The additional reasons for this condition are the fact that the domain and codomain of the compound function were constantly expressed as $R \rightarrow R$ and the students were not ready for performing operations with the equations of the second degree.

Table 6. The Answers Given by the Students to the Sixth Question

\begin{tabular}{|c|c|c|}
\hline Frequency & Answers & $\begin{array}{c}\text { Basic Foundations of } \\
\text { the Answers }\end{array}$ \\
\hline 27 & $\begin{array}{l}\text { Since every element has an } \\
\text { image in the graphs in options } \\
\text { ' } a \text { ' and 'c', they denote } \\
\text { functions. Since the elements } \\
\text { have more than one image in } \\
\text { options 'b' and 'd', they do } \\
\text { not denote functions. }\end{array}$ & $\begin{array}{l}\text { The correct answer } \\
\text { was given for the } \\
\text { graphs' state of being } \\
\text { or not being functions. }\end{array}$ \\
\hline 10 & $\begin{array}{l}\text { Since a parallel line intersects } \\
\text { the graphs on a single point } \\
\text { when it is drawn to the graphs } \\
\text { in options 'b' and 'd', they } \\
\text { denote functions. Since it } \\
\text { intersects on two points, they } \\
\text { do not denote functions. }\end{array}$ & $\begin{array}{l}\text { The condition of a } \\
\text { line's intersecting on } \\
\text { one point, which is } \\
\text { expressed as the } \\
\text { graphs' state of } \\
\text { denoting functions, } \\
\text { was perceived as } \\
\text { parallel to } x \text { axis. }\end{array}$ \\
\hline 5 & $\begin{array}{l}\text { Since the graph intersects } x \\
\text { and } y \text { axes on two points, the } \\
\text { graphs in options 'c' and ' } d \text { ' } \\
\text { do not denote functions. The } \\
\text { graphs in options 'a' and 'b' } \\
\text { denote functions. }\end{array}$ & $\begin{array}{l}\text { The expression "a } \\
\text { parallel line, which is } \\
\text { drawn on the graph } \\
\text { along the } y \text { axis, does } \\
\text { not intersect the graph } \\
\text { at two points" was } \\
\text { perceived as a valid } \\
\text { condition for the } x \\
\text { axis. }\end{array}$ \\
\hline 7 & Unrelated answer & $\begin{array}{l}\text { Unrelated statements } \\
\text { were made because the } \\
\text { question was not fully } \\
\text { understood. }\end{array}$ \\
\hline 3 & Unanswered & No answer was given. \\
\hline
\end{tabular}

When Table 6 was examined, it was observed that 27 students answered this question correctly. The ratio of correct answers to this question is high, but there are notable answers. For instance, 10 students stated that when a parallel line is drawn to the $x$ axis and it intersects on a single point on the graph, this denote functions. They stated that lines that intersect on two points do not denote functions. Five students evaluated in accordance with whether or not the graph intersected the axes, and they defined the one which intersected on more than one point as a function. Excerpts from the interviews conducted with one student and one teacher to determine the reasons for mistakes, as well as the answer of the same student, are given below.

$\mathbf{S}_{2}$ : “...In order for a graph to denote a function, the parallel lines, which are drawn on the graph, need to intersect the graph at two points. When these lines, which are drawn on the graph, intersect the graph at two points, they are not functions..."

$\mathbf{T}_{3}$ : “...When such types of questions are given, the requirements that must be fulfilled to denote a function are explained to the students with their reasons. When the students cannot fully learn a concept, they use memorization-based practical techniques. In the courses, it is emphasized that parallel lines are drawn on the y axis in order to determine practically whether or not it is a function. However, since parallel lines are similarly drawn on the $x$ axis in one-to-one functions, these two cases were confused with each other and lead to incorrect answers..." 


\section{6) Aşağıdaki grafiklerden hangileri fonksiyon belirtebilir? Nedenleri ile açıklayınız.}
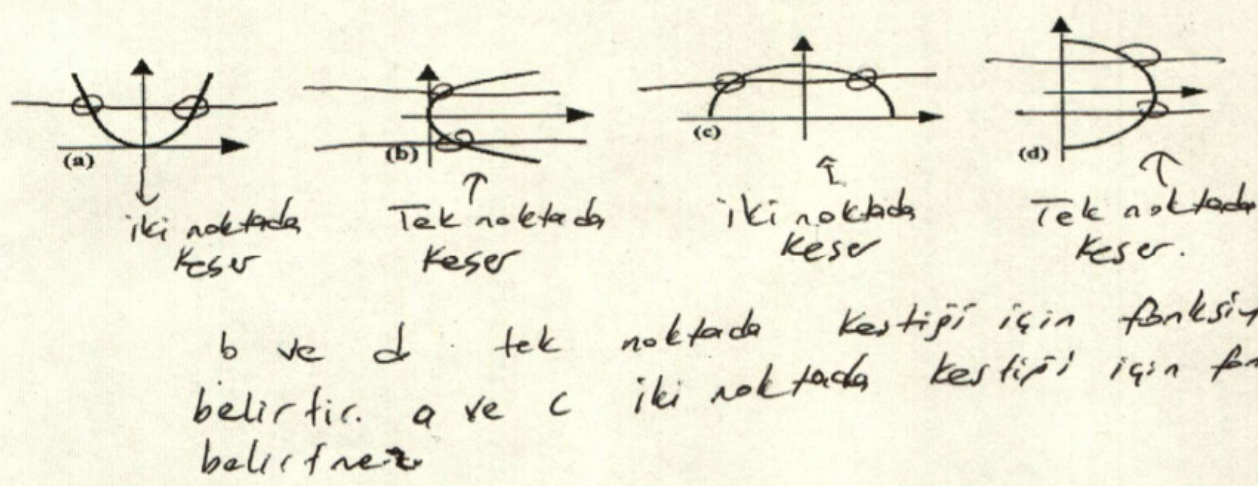

Figure 4. Given by one of the Students Answered the Fourth Question

When the data is examined, it is observed that there are significant mistakes. The students who made mistakes did so in a similar fashion by drawing parallel lines on the $x$ or $y$ axis instead of contemplating the requirements of a function. As it was expressed in the interview conducted with the teacher, such mistakes resulted from the fact that the students were not able to fully perceive the concept and they developed a practical approach. Moreover, another reason for the mistake is that it was associated with drawing a parallel line on the $x$ axis that is used when the function is one-to-one.

Table 7. The Answers Given by the Students to the Seventh Question

\begin{tabular}{ccc}
\hline Frequency & Answers & $\begin{array}{c}\text { Basic Foundations of the } \\
\text { Answers }\end{array}$ \\
\hline 6 & $\begin{array}{c}\text { The function is } \\
\text { one-to-one and linear, } \\
\text { but not surjective. }\end{array}$ & $\begin{array}{c}\text { Types of function were } \\
\text { correctly expressed. }\end{array}$ \\
\hline 3 & $\begin{array}{c}\text { The function is } \\
\text { one-to-one, linear and } \\
\text { surjective. }\end{array}$ & $\begin{array}{c}\text { It was evaluated as surjective } \\
\text { considering the fact that } \\
\text { every element in the function } \\
\text { had an image. }\end{array}$ \\
\hline 20 & Unrelated answer & $\begin{array}{c}\text { Unrelated statements were } \\
\text { made because the question } \\
\text { was not fully understood. }\end{array}$ \\
\hline 23 & Unanswered & No answer was given. \\
\hline
\end{tabular}

When the table is examined, it is observed that students experienced great difficulty with this question. The number of unrelated and blank answers is very high. Twenty-three students did not answer the question. Twenty students gave unrelated answers to this question. Excerpts from the interviews conducted with one student and two teachers are given below.

$\mathbf{T}_{3}$ : “...When types of function are given to the students, the representation of the sets are rather in the form of a Venn diagram. It is easier for students to understand it this way. Students' unfamiliarity with expressing the types of a function that is given as an equation system caused this condition to emerge..."

$\mathbf{T}_{2}$ : “...Students might not been able to fully associate the concepts of domain and codomain with each other for function's being one-to-one and surjective. Furthermore, the fact that there were no visual statements and that the function required an abstract perception caused the students to make mistakes..."

$\mathbf{S}_{6}$ : “...Since every element has an image in the domain, it is one-to-one and surjective. Moreover, it is linear since the equation is of the first degree..."

As it can be understood from the above-mentioned statements, students experience great difficulty in expressing the types of functions. It is a worrisome fact that such a condition emerged, despite the given function being comprehensible. In the light of the interviews conducted with the teachers, the reason for the mistakes is the fact that students are not familiar with this type of question since the types of function are generally given using a Venn diagram. It is not easy for the students to perceive and evaluate a function that is given in the form of an equation. Consequently, another reason for the mistakes is the fact that this type of question is not featured in mathematics courses.

Table 8. The Answers Given by the Students to the Eighth Question

\begin{tabular}{|c|c|c|}
\hline Frequency & Answers & $\begin{array}{c}\text { Basic Foundations of the } \\
\text { Answers }\end{array}$ \\
\hline 1 & $\begin{array}{l}\text { It is defined for all natural } \\
\text { numbers except for } 2 \text {, } \\
\text { which makes the function } \\
\text { not defined and } 0 \text { and } 1 \text {, the } \\
\text { images of which are } \\
\text { negative. }(N-\{0,1,2\})\end{array}$ & $\begin{array}{l}\text { The condition which was } \\
\text { required for the } \\
\text { expression to denote a } \\
\text { function was correctly } \\
\text { expressed. }\end{array}$ \\
\hline 16 & $(N-\{2\})$ & $\begin{array}{l}\text { Only the value which } \\
\text { made the function not } \\
\text { defined was taken into } \\
\text { consideration. }\end{array}$ \\
\hline 5 & $\begin{array}{l}\text { Every element must have } \\
\text { an image, and no element } \\
\text { must be left unpaired. }\end{array}$ & $\begin{array}{l}\text { The general definition } \\
\text { for the state of being a } \\
\text { function was given. } \\
\text { However, no explanation } \\
\text { was made for the given } \\
\text { expression. }\end{array}$ \\
\hline 13 & Unrelated answer & $\begin{array}{c}\text { Unrelated statements } \\
\text { were made because the } \\
\text { question was not fully } \\
\text { understood. } \\
\end{array}$ \\
\hline 17 & Unanswered & No answer was given. \\
\hline
\end{tabular}




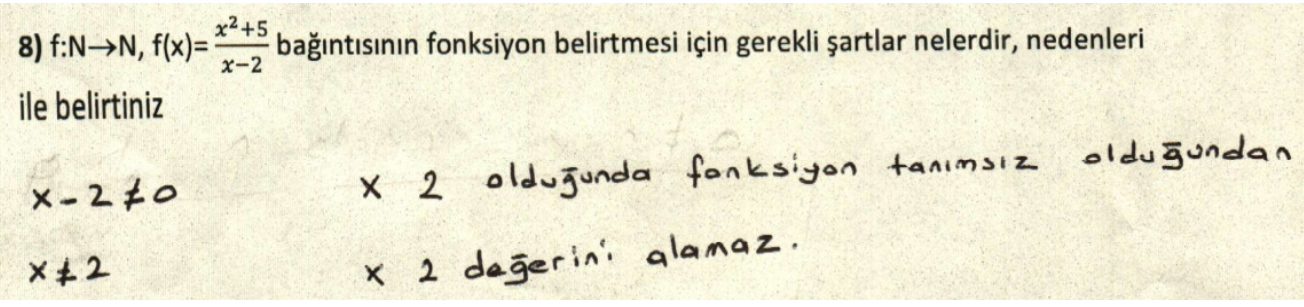

Figure 5. Given by one of the Students Answered the Fifth Question

When Table 8 is examined, it is observed that only one student correctly expressed the conditions that were necessary for the given function to be defined. Sixteen students stated that it would not be defined in the value 2 that made the denominator 0 , but they did not state that the values 0 and 1 were also not defined for the given function. Excerpts from the interviews conducted with one teacher and one student to determine the reasons for the mistakes, as well as the answer of the same student, are given below.

$\mathbf{S}_{10}$ : "...The denominator must not be 0 in order for the given relation to denote a function. Therefore, we cannot assign the value 2 to $x$. Furthermore, no elements must be left unpaired and every element must have an image. There is no problem since it is defined in other numbers..."

$\mathbf{T}_{4}$ : “...Students make mistakes in this question since a function's state of being defined is taught in later years. In this question, they only stated that the denominator must not be 0 . The students can better express a relation's state of being a function with a Venn diagram and listing methods. They only focus on the given relation in these questions by performing one-to-one correspondence. Domain and image sets are not taken into consideration..."

When the above given data was examined, it was observed that the students experienced problems in expressing the domain of the function. As it was also expressed in the interview conducted with the teacher, the students made these mistakes since they rarely use the algebraic notation, although they generally use the Venn diagram and listing method. Moreover, the fact that the students do not encounter such types of questions and they only consider the given relation and do not consider domain and image set is shown as another reason.

\section{Discussion and Conclusions}

This study revealed the mistakes made by the Anatolian ninth grade students in the subject of functions and the reasons for these mistakes. When the obtained data was examined, it was observed that the students experienced problems in the subject of functions and they made various mistakes. The mistakes of the students in the subject of functions as well as the reasons for these mistakes are given below.

More than half of the students were not able to solve the first question that was related to the definition of function, and they made various mistakes. These mistakes are as follows: they believed that the fact that no elements were left unpaired in the domain single-handedly fulfilled the requirement for being a function; they believed that no element must be left unpaired in the codomain either; and the requirement that every element in the domain has a single image was perceived as a requirement for the elements in the codomain. The fact that the students memorize the requirements for a given relation to be a function comes forward as the reason for these mistakes [27]. This result shows similarity with the findings of the study of [28]. The students made operational mistakes resulting from the fact that the function was of the second degree in the second question that was related to taking the inverse of a function that was denoted in the form of an equation of the second degree. Furthermore, some students gave incorrect answers by implementing the rule of taking the inverse of a function of the first-degree on the equations of the second degree. In view of the conducted interviews $\left(\mathrm{T}_{1}\right)$, the reasons for these mistakes are revealed as follows: students' inefficiency in operational skills resulting from the fact that they are not ready for the operations related to the equations of the second degree; such types of questions are not featured in the courses; they meaninglessly memorize the rule of taking the inverse of a function in the equations of the first-degree. In the question which asked whether or not a relation depending on $y$ was a function, some students answered incorrectly, stating that the function must be dependent on $x$ not $y$ [29]. As it was also stated in the interview $\left(\mathrm{T}_{3}\right)$, the most basic reason for these mistakes is the fact that the functions are explained in sourcebooks, and courses generally, as depending on $x$. This result shows similarity with the findings of the study of [30]. In the question that featured domain, codomain and image set, the majority of the students correctly expressed the domain, but they gave incorrect answers in expressing the image set and the codomain. These mistakes are as follows: image set and codomain were confused with each other and evaluated as the same concepts. It was understood from the conducted interviews that these mistakes were made due to the fact that these concepts were not given much emphasis in mathematics courses and sources, and accordingly, these concepts were not learned by the students at conceptual level.

None of the students was able to give a correct answer to the fifth question that was related to the compounds of two 
functions that were given as equations of the second degree. The mistakes made by the students are as follows: they overlooked the compound function's state of being defined and they made mistakes on operation stages. In view of the conducted interviews $\left(T_{1}, T_{4}\right)$, the reasons for the mistakes can be listed as follows: the students had not previously encountered a compound function's state of being defined or not defined; domain and codomain of the compound function are always expressed as $R \rightarrow R$ in courses and source books; and the students were not ready to perform operations in the equations of second-degree. In the question that asked which of the relation graphs denoted a function, it was observed that some students made conceptual mistakes utilizing the statements [16, 27], "parallel lines are drawn to the axes and it is not a function if they intersect the graph of the relation on more than one point". Some students drew parallel lines to the $x$ axis and interpreted accordingly. Moreover, some students evaluated the graphs, which intersected the axes at two points, as functions. In view of the information obtained from the interviews $\left(\mathrm{T}_{3}\right)$, the reason for this condition is the fact that a memorization-based understanding emerged in order to develop a practical approach since the concept was not fully perceived. Another reason is that it was associated with drawing a parallel line to the $x$ axis that is used when the function is one-to-one. It was observed that the students experienced great difficulty in the seventh question that examined whether a given function was one-to-one, surjective or linear. Six students answered this question correctly. In view of the interviews conducted with the teachers $\left(T_{3}, T_{2}\right)$, the basic reasons for the difficulties experienced in this question were stated as follows: the use of the equation system instead of a Venn diagram that is frequently encountered by the students in the questions that contain these concepts; abstract thinking, which involved domain, codomain and image set, was required for the question. These findings show parallelism with the findings of [34]. One student answered the eighth question, which requested the necessary conditions for a relation, which was defined from natural numbers to natural numbers to denote a function, correctly. Some of the students considered the value that made the denominator 0 without paying attention to the studied sets. It is also observed that the number of blank and unrelated answers is high. In view of the conducted interviews $\left(\mathrm{T}_{4}\right)$, the fact that the students did not use the algebraic notations in such kinds of questions is observed as a significant reason for these mistakes. Moreover, another reason seems to be the fact that domain and codomain were not considered while examining the requirements for a relation to be a function.

By nature, functions are not easy to perceive by students. Therefore, it is one of the subjects where misconceptions and mistakes are intensively experienced. Some changes have to be implemented in teaching the functions that hold importance, considering that they have the feature of combining the mathematical concepts and associating them with real life [2, 21]. The fact that rather operational properties are emphasized in teaching functions prevents effective learning. Accordingly, students make mistakes about the functions as a result of memorization-based learning [31]. To study operational properties as well as conceptual properties in detail; to show the transitions among notations such as algebraic, graphic and table form; and to associate them with real life will increase the effect in function teaching. Since students determine their approaches in accordance with the questions that they come across, the question types must have features that require contemplation [32]. Furthermore, it constitutes another problem that the ninth grade students are not ready for some concepts that are required for functions. For this reason, the subject of functions must be given after the basic subjects instead of within the first semester of the ninth grade. Thus, students will obtain basic acquisitions and they will be ready for a subject like functions that incorporates different acquisitions.

\section{Questions}

1) Given that $\mathrm{A}=(1,2,3,4)$ and $\mathrm{B}=(\mathrm{a}, \mathrm{b}, \mathrm{c}, \mathrm{d}, \mathrm{e}, \mathrm{f})$, and $\mathrm{f}: \mathrm{A} \rightarrow \mathrm{B}$, does the relation $\mathrm{f}:(1, \mathrm{~b}),(2, \mathrm{c})(3, \mathrm{c}),(4, \mathrm{e})$ make a function

2) Find $f^{-1}(\mathrm{x})$ if $\mathrm{f}(\mathrm{x})=x^{2}+4 \mathrm{x}$.

3) Is $\mathrm{f}(\mathrm{y})=5 \mathrm{y}+3$ a function?

4) Given that $\mathrm{A}=(1,2,3)$ and $\mathrm{f}: \mathrm{A} \rightarrow \mathrm{N}$, what are the domain, codomain, and range sets for the function $f(x)=x+1$ ?

5) Do $f(x)=2$ and $f(x)=x$ have inverse functions? If yes, find them.

6) If $\mathrm{f}(\mathrm{x})=x^{2}+2$ and $\mathrm{g}(\mathrm{x})=x^{2}-4$, find $\operatorname{gof}(\mathrm{x})(?)$

7) Which ones of the following graphs can be assigned a function? Why?

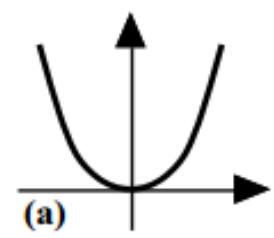

(b)
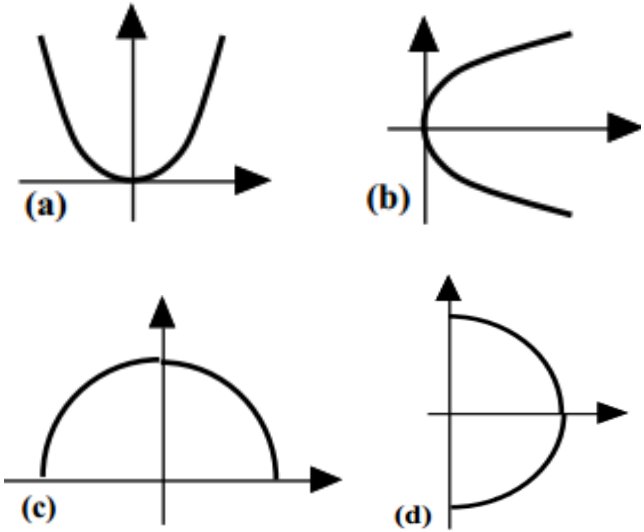

8) What are the conditions necessary for the relation $\mathrm{f}: \mathrm{N} \rightarrow \mathrm{N}, \mathrm{f}(\mathrm{x})=\frac{x^{2}+5}{x-2}$ to be a function?

\section{REFERENCES}

[1] Sajka, M. (2003). A Secondary School Student's Understanding of the Concept of Function - A Case Study. Educational Studies in Mathematics, 53, 229-254.

[2] Bayazıt, İ. veAksoy, Y. (2010). Öğretmenlerin Fonksiyon 
Kavramı ve Öğretimine İlişkin Pedagojik Görüşleri. Gaziantep Üniversitesi Sosyal Bilimler Dergisi, 9(3), 697-723.

[3] Malik, M. A. (1980). Historical and Pedagogical Aspects of The Definition of Function. International Journal of Mathematical Education in Science and Technology, 11(4), 489-492.

[4] Baki, A. (2008). Kuramdan Uygulamaya Matematik Ĕgitimi. Ankara: Harf Eğitim Yayıncılık.

[5] Dubinsky, E., and Harel, G. (1992). The concept of function: Aspects of Epistemology and Pedagogy. Washington, DC: Mathematical Association of America.

[6] Sierpinska, A. (1992). On Understanding the Notion of Function. In G. Harel and E. Dubinsky (Eds.), the Concept of Function, Aspects of Epistemology and Pedagogy, (Vol. 25, Pp. 25-58). USA: Mathematical Association of America.

[7] Vinner, S. (1983). Concept Definition Concept Image and the Notion of Function. International Journal of Mathematics Education in Science and Technology, 14(3), 293-305.

[8] Akkoç, H. (2005). Fonksiyon Kavramının Anlaşılması: Tanımsal Özellikler ve Çoğul Temsiller. Eğitim Araştırmaları Dergisi (Eurasian Journal of Educational Research), 20, $14-24$.

[9] Bayazıt, İ (2011) .Öğretmen Adaylarının Grafikler Konusundaki Bilgi Düzeyi. Gaziantep Üniversitesi Sosyal Bilimler Dergisi, 10(4), 1325-1346.

[10] Clement, L. (2001). What Do Students Really Know About Functions?,The Mathematics Teacher, 94(9): 745-748.

[11] Dede, Y., Bayazit, İ veSoybaş, D. (2010). Öğretmen Adaylarının Denklem, Fonksiyonve Polinom Kavramlarını Anlamaları. Kastamonu Ĕ̈itim Dergisi, 18(1), 67-88.

[12] Dikici, R. veİşleyen, T. (2003). Bağıntıve $\quad$ Fonksiyon Konusundaki Öğrenme Güçlüklerinin Bazı Değişkenler Açısından İncelenmesi. Kastamonu Eğitim Dergisi, 11(2), 105-116.

[13] Hitt, F. (1998). Difficulties in Articulation of Different Representations Linked to the Concept of Function. Journal of Mathematical Behavior, 17(1), 123-134.

[14] Janvier, C. (1998). The Notion of Chronicles as an Epistemological Obstacle to the Concept of Functions. Journal of Mathematical Behavior, 17(1), 79-103.

[15] Kabael, T.U. (2010). Fonksiyon Kavramı: Tarihi Gelișimi, Öğrenilmesi, Öğrenci Yanılgılarıve Öğretim Stratejileri. TUBAV Bilim Dergisi, 3(1), 128-136.

[16] Tall, D., and Bakar, M. (1992). Students Mental Prototypes for Functions and Graphs. International Journal of Mathematics Education in Science and Technology, 23(1), 39-50.

[17] Ural, A. (2006). Fonksiyon Öğretiminde Kavramsal Zorluklar. Ege Eğitim Dergisi, 7(2), 75-94.

[18] Ural, A. (2012). Fonksiyon Kavramı:Tanımsal Bilginin Kavramın Çokluğu Temsillerine Transfer Edilebilmesive Bazı KavramYanılgıları. Pamukkale Üniversitesi Eğitim Fakültesi Dergisi, 31(1), 93-105.
[19] Dede, Y. (2004). Öğe Gösterim Teorisi'nin Bir Uygulaması: Fonksiyon Kavramının Öğretimi. Gazi Üniversitesi Kırşehir Ĕ̆itim Fakültesi Dergisi, 5(2), 287-297.

[20] Eisenberg, T. (1991). Function and Associated Learning Difficulties. D. O. Tall (Eds.), Advanced Mathematical Thinking. Dordrecht: Kluwer Academic Publishers.

[21] Kabael, T. U. ve Tanışl1, D. (2010). Cebirsel Düşünme Sürecinde Örüntüden Fonksiyona Öğretim. Illköğretim Online, 9(1), 213-228.

[22] Leinhardt, G., Zaslavsky, O., and Stein, M. K. (1990). Functions, Graphs, and Graphing: Tasks, Learning, and Teaching. Review of Educational Research, 60(1), 1-64.

[23] Montiel, M., Vidakovic, D., and Kabael, T. (2008). Relationship between Students' Understandings of Functions in Cartesian and Polar Coordinate Systems. Investigations in Mathematics Learning, 1(2), 52-70.

[24] Narlı, S. ve Başer, N. (2008). "Küme Bağıntı Fonksiyon" Konularında BirBaşarı Testi Geliştirmeve $\mathrm{Bu}$ Test İle Üniversite Matematik Bölümü 1. Sınıf Öğrencilerinin Bu Konulardaki Hazırbulunuşluklarını Betimleme Üzerine Nicel Bir Araştırma. Dokuz Eylül Üniversitesi Buca Ĕ̈itim Fakültesi Dergisi, 24, 147-158.

[25] Vidakovic, D. (1996). Learning the Concept of Inverse Function. Journal of Computers in Mathematics and Science Teaching, 15(3), 295-318.

[26] McMillan, J. H., and Schumacher, S. (2010). Research in Education: Evidence-Based inquiry (6th Edition). Boston: Pearson.

[27] Akkoç, H. (2004). Lise 3 Öğrencilerinin Çekirdek Fonksiyon Kavramını Anlamaları. 6. Ulusal Fen Bilimlerive Matematik Ĕ̌itimi Kongresi, Marmara Üniversitesi, İstanbul.

[28] Aydın, M. veKöğce, D. (2008). ÖğretmenAdaylarının "DenklemveFonksiyon" KavramlarınallişkinAlgıları. YüzüncüYılÜniversitesiEğitimFakültesiDergisi, 5(1), 46-58.

[29] Özmantar, M. F., Bingölbali, E. ve Akkoç, H. (2010). Matematiksel Kavram Yanılgılarıve Çözüm Önerileri. Ankara: Pegem Akademi Yayıncılı.

[30] Soylu, Y. (2010). The Models Used by Elementary School Teachers to Solve Verbal Problems. Australian Journal of Teacher Education, 35(4), 25-40.

[31] Keller, B.A., and Hirsch, C.R. (1998). Student Prefences for Representation of Functions. International Journal of Mathematics Education in Science and Technology, 29(1), $1-17$.

[32] Yavuz, İ. Ve Baştürk, S. (2011). Ders Kitaplarında Fonksiyon Kavramı: Türkiyeve Fransa Örneği. Kastamonu Eğitim Dergisi, 19(1), 199-220.

[33] Tatar, E. ve Dikici, R. (2008). Matematik Eğitiminde Öğrenme Güçlükleri. Mustafa Kemal Üniversitesi Sosyal Bilimler Enstitüsü Dergisi, 5(9), 183-193.

[34] Polat, Z. S. ve Şahiner, Y. (2007). Bağıntıve Fonksiyonlar Konusunda Yapılan Yaygın Hataların Belirlenmesive Giderilmesi Üzerine Boylamsal Bir Çalışma. Eğitimve Bilim Dergisi, 32(146), 89-95. 